\section{The masonries of the Roman bridge of Sant'Antioco (Sardinia, Italy)}

\section{Caterina Giannattasio, Silvana Maria Grillo}

Dipartimento di Ingegneria Civile, Ambientale e Architettura - DICAAR, Università degli Studi di Cagliari, Italy

\begin{abstract}
The bridge of Sant'Antioco is an architectural specialty dating back most probably to Roman origin, interested by many other interventions during the following centuries. It represents a piece of art of a unique road net in its kind, for its function in connecting not only the opposite banks of a river but also a small island with the dry land. Additionally, its architectural design does not have any analogies in other episodes. It has been studied following an interdisciplinary approach, with the aim of combining the historical, architectural and constructive knowledge with methods used in geologic and geochemical investigations, intending to elucidate the various phases that this architectural monument underwent within the course of the centuries. Specifically, the ultimate goal of the present research is to gain a more profound comprehension of this architecture, which is essential to define a correct and qualified restoration and conservation process.
\end{abstract}

\section{Introduction}

The bridge is situated in a very suggestive context, on the west Sardinia coast, with the function of linking it with the little island of Sant'Antioco, following faithfully the original Roman path. Visible during the periods of low tide, it is placed to the right of the road leading to the island. Going towards the bridge we can find, on the left side, the Gulf of Palmas and, on the right, the Sant'Antioco pond (Figure 1). It has been object of many interventions during the centuries that compromised the conservation of the primitive constructions. Many archeologists analyzed thoroughly this aspect, concluding that actually only the foundations coincide with the Roman ones. Very significant for this study has been the consultation of historical archive documents, already known in literature.

More than fifty years of abandonment caused a progressive decay of this significant construction. By consequence, the present research wants to put in evidence its peculiar historical, architectural, technical and material aspects, i.e. to build a solid basis for future restoration.

\section{Historical events}

The ancient Sant'Antioco city's name is Sulci (Spano, 1857; Bartoloni, 1989), already flourishing in the Punic city, which experienced a moment of strong growth in Roman times, when in the second century B.C. the execution of important works was carried out (Meloni, 1975, 1988; Tronchetti, 1984, 1995; Bernardini, 1990; Manconi, 1976).

In the second half of the century it experienced a moment of crisis, with a recovery in Claudian times (first century AD), which persisted throughout the second century, but its importance sank in the Severan age (III), unlike other cities in Sardinia (Ghiotto, 2004).

Already object of other studies, the Sant'Antioco bridge was once called Pontimannu i.e. big bridge, leaving to assume the existence of a system of other small bridges that once guaranteed the passage between the various islands of the isthmus.

As we said before, probably founded by the Romans, it has undergone numerous and substantial restoration, documented from archival sources. We refer in particular to an estimate of the second half of the eighteenth century, to make traffic on old bridge that connects the island of Sant'Antioco to the coast of the Kingdom (Fois, 1964).

Another important document concerns the draft drawn up by architect Gaetano Cima, dated April 13, 1839, dealing with the renovation of the bridge (Cagliari State Archive, 1839). This document includes a graphic (Figure 2), where is designed the longitudinal profile, the plan - with reference to which it is reported that the parts in red indicate the new buildings, while these in grey the existing structures -, the cross section and finally Half of the prospectus of the Bridge restored.

The plan also shows the presence, towards the west, of a construction, called Fort said of the bridge. The project involved the redefinition of new shares in order to obtain a more regular driveway, widening the road section, from 5 to $6 \mathrm{~m}$. Two reports are attached to the project, one consisting of a Metric computation, the other one titled Calculation and Instructions.

As is clear from reading these documents, it is easy to see that at the time the term restoration was used with a meaning totally different from the contemporary one. It was in fact real restructuring, rehabilitations, reconstructions, rather than conservation projects. In other words, the examined case explains the attitude toward existing buildings that marked the nineteenth century in the area under examination. It was marked by the lack of a rigorous
Correspondence: Caterina Giannattasio, Dipartimento di Ingegneria Civile, Ambientale e Architettura - DICAAR, Università degli Studi di Cagliari, via Corte d'Appello 59, 09124 Cagliari, Italy.

Tel. +39.347 .6860069 - Fax: +39.070 .6755818 .

E-mail: cgiannatt@unica.it

Key words: interdisciplinarity, historical building techniques, masonries, stratigraphy.

Contribtions: $\mathrm{CG}$ is the author of the paragraphs Historical events and The building: architectural and technical aspects; SMG wrote Results and Discussion; CG and SMG together compiled the Introduction, The interdisciplinary investigations and the Conclusions.

Citation: Giannattasio C, Grillo SM, 2014. The masonries of the Roman bridge of Sant'Antioco (Sardinia, Italy). In: RH Tykot (ed.) Proceedings of the $38^{\text {th }}$ International Symposium on Archaeometry - May $10^{\text {th }}-14^{\text {th }} 2010$, Tampa, Florida. Open Journal of Archaeometry 2:5458.

Presented at the $38^{\text {th }}$ International Symposium on Archaeometry - May $10^{\text {th }}-14^{\text {th }} 2010$, Tampa, Florida.

This work is licensed under a Creative Commons Attribution 3.0 License (by-nc 3.0).

(C) Copyright C. Giannattasio and S.M. Grillo, 2014 Licensee PAGEPress, Italy

Open Journal of Archaeometry 2014; 2:5458 doi:10.4081/arc.2014.5458

philosophy of conservation, which led to intervene in the existing building without thinking critically to such significant historical aspects. The solutions adopted for the bridge denote the absence of a specific language, a trend time to compose the new rather than to respect the ancient.

After the Cima's project the bridge has been object of other interventions in 1858, in 1893 and 1920. Since 1940, as a result of a filling work intended to facilitate the passage for military vehicles to achieve the platform or the carriage of goods without crossing the old construction, it was partially submerged in the ground, impeding a complete overview of its structure.

After 1954, with the opening of the variant road, the bridge was abandoned, becoming monument of himself.

Only in 2006 a conservation project by the Superintendence for Architectural Heritage, Landscape, Historical, Artistic and Ethnoanthropological Heritage of the provinces of Cagliari and Oristano has been carried out. 


\section{Materials and Methods}

\section{The interdisciplinary investigations}

The construction has been explored following an interdisciplinary approach. Specifically, it has been studied from an architectural point of view, through on-the-spot investigation, with the analysis of masonries, by showing their structural aspects and the executive modalities for their setup.

The use of photogrammetric programs allowed a punctual graphical restitution of the architecture, putting in evidence the dimensional and material aspects, as well as the conservation questions to deal with, in a future project phase.

Metric and photographic surveys supported by drawings highlighted the constructive peculiarities of the buildings analysed.

On the other hand, it has been studied by mineralogical-petrographic and geochemical methods for the characterization of building materials used, and mainly by the analysis of plasters and mortars, to define their main features and to try to identify the provenance area of the materials used and the restoration of the bridge during the historical period.

In the future it is planned to complete punctual surveys and graphic archaeological illustrations and descriptions intending to elucidate the various phases that this architectural monument underwent within the course of the centuries.

\section{The building: architectural and technical aspects}

The architectural structure is made up of ramps converging towards two barrel-vaulted arches about $5.0 \mathrm{~m}$ large (Fois, 1964; Mattazzi, 1996), which some researchers suppose they may originally be three (Tronchetti, 1984). These arches are made of square blocks of sandstone, as we can see on the both at the north and the south prospectus. They are framed in masonry composed of rhyolitic rough-hewn ashlars of various sizes. In the east part of the south façade we can find the use of very irregular sandstones (Figure 1). Also with reference to the interstitial mortar, there is a variety of types, some of which recently have been realized during the last restoration. They show the same mixture, ingredients and mixing proportions, but with different colors and shades, depending on their position, i.e. lighter near the sandstone and darker near the rhyolitic elements.

The different colors of the materials (yellow for the sandstone, dark-red for the rhyolite) play a significant role in the formal definition of the architecture, in which the two mentioned arcades are put in evidence. This effect is evident thanks to the almost total loss of plaster. In fact the latter has been preserved only at some parts of northern prospectus, and it is also in a precarious state, keeping only the deeper layer (arriccio), and then having lost the outer layers of the finishing. This arriccio, which is characterized by the predominant presence of gravel, has also been found on the southern front, though more rarely, this being the side most exposed to the wind.

With reference to the masonries, as we can see, the various changes have contributed to their deterioration and structural composition. In fact, at the arches, in some places regular sandstone blocks have been replaced with smaller-sized rustic stones of the same material (Figure 3). Even in some of the rhyolite

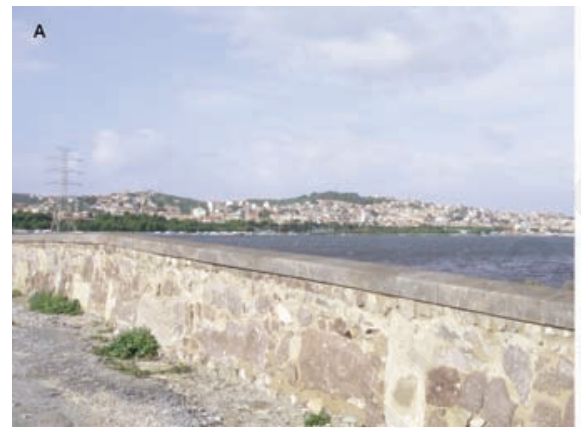

\section{B}

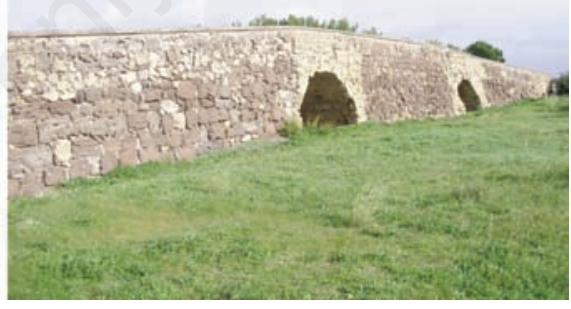

Figure 1. View of Sant'Antioco town from the bridge (A) and detail of the south front (B).

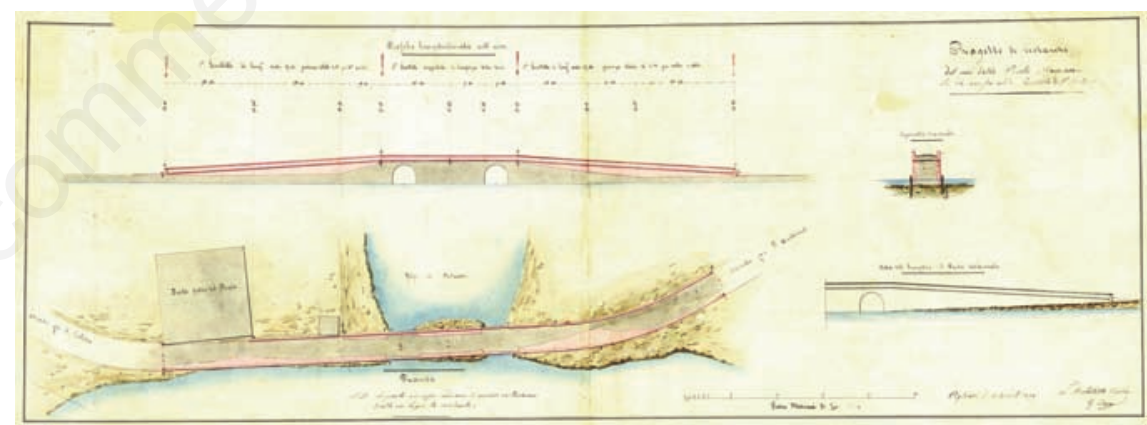

Figure 2. The restoration project signed by the architect Gaetano Cima, XIX century. Reproduced with permission of the Ministero per i Beni e le Attività Culturali, (c)Archivio di Stato di Cagliari. All rights reserved (Rif. n. 1608/28.13.12, 17 December 2009).
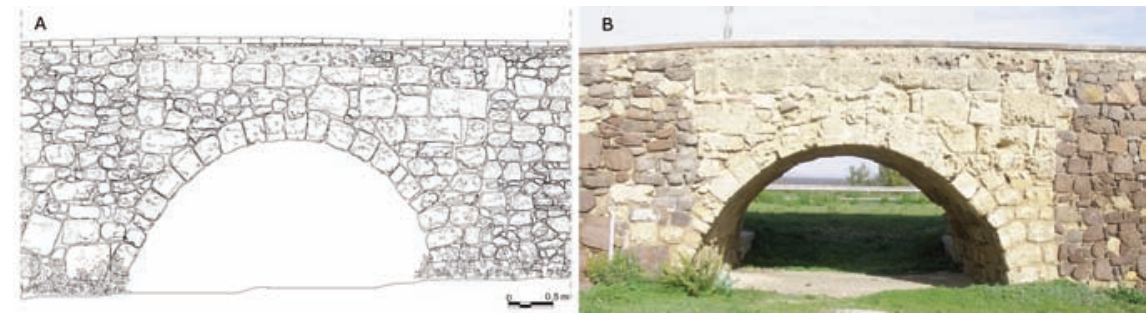

Figure 3. Drawing (A) and picture (B) of one of the arches of the south prospectus (drawing by courtesy of V. Pintus and M. Porcu). It shows an advanced degradation, with the presence of alveolisation, pulverisation and pitting processes. 
weathering - and on the other hand is the results of successive inappropriate human interventions, i.e. in successive updates, including that one conceived by Cima. Thus, it is currently characterized by a situation of total chaos, from a formal and technical point of view.

Also the use of the structure till a few years ago has certainly contributed to its collapse, as evidenced by the ancient cobbled pavement, which were stacked several layers, including a recent coat of bituminous layer.

\section{Results and Discussion}

Usually the architecture of many towns of the world has been influenced by the stones occurring in the area. By consequence, the knowledge of the geological situation of a territory, the distribution of litotypes, the knowledge of their physic-mechanical features and their weathering phenomena is very significant to carry out the restoration project (Herrmann et al., 2002).

Almost all buildings of Sant'Antioco inland have been built with local stone materials, most of them are Cenozoic volcanic rocks, mainly rhyolites and to a lesser extent andesites and basalts, commercially known under the name of trachyte auctorum. In Sardinia the use of trachytes auctorum as building and ornamental stones dates back to prehistoric times to present days, as demonstrated by the many buildings achieved also by Romans. Cretaceous bioclastic limestones, marly and oolitic limestone outcrop in the inland, but are much less used for the building.

In the specific case, the bridge is prevalently made of two different types of stones: i) sandstone, used as regularly cut blocks mainly for arches; ii) rhyolite rock used as regular and irregular shape in the masonry; iii) some limestone ashlars (Figure 3). While the rhyolite trachyte auctorum - is well conserved and simply shows different patinas, the sandstone shows a deeper degradation (Prokos, 2008), as it is testified by the presence of exfoliation, disintegration, loss of strength and alveolization phenomena (Figure 5).

The aggregates in the mortars are of different kind from a granulometric and chromatic point of view, while petrographically they are characterized by quartz, k-feldspar, fossil fragments, carbonate and fragments of quartzite and volcanic rocks. The difference in the petrographical composition is linked to the different kinds of mortars, used during the several restoration projects that involved the building (Figure 6).

The plaster contains coarse grains; in the north façade the aggregates are poor assorted, while those in the south are well assorted. In

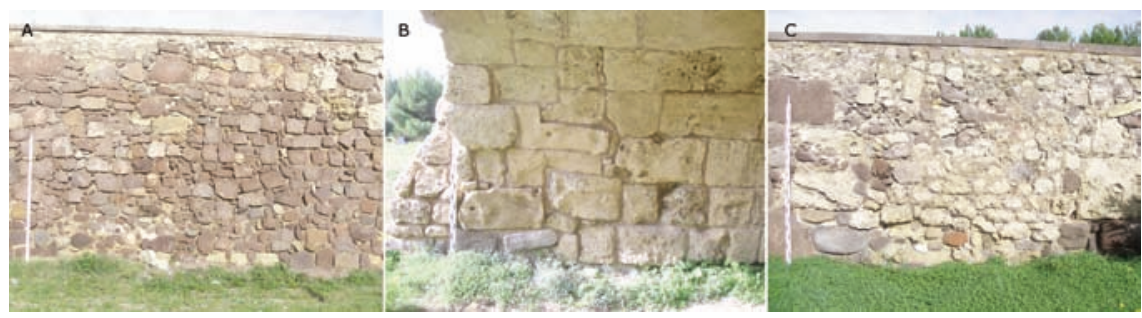

Figure 4. Sequence of the masonries concerning the south façade: A) part near the first arches towards west; B) detail of the interior of one of the arches; C) the terminal part towards east.

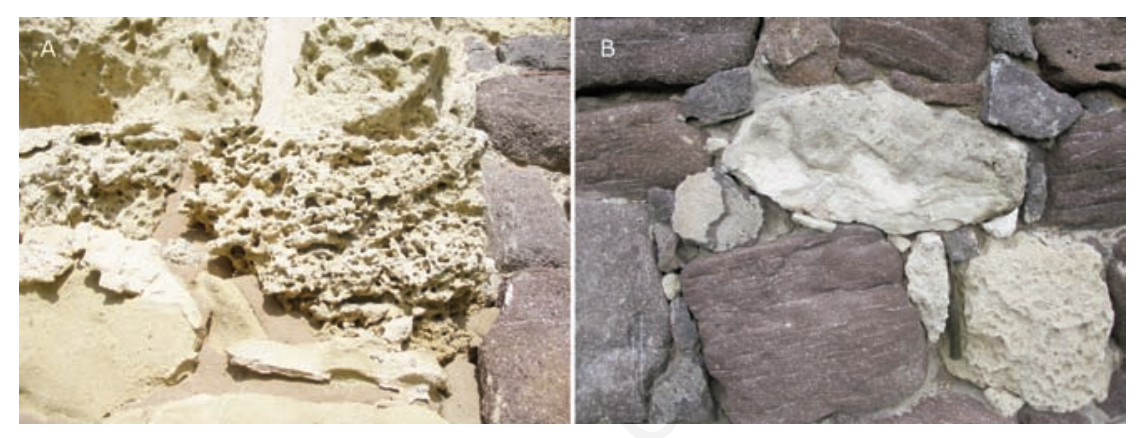

Figure 5. A) Sandstone ashlars composing the arches. Some of them show a deep alveolisation phenomenon. B) Rhyolite, limestone and sandstone ashlars, characterising the masonry surrounding the arches.

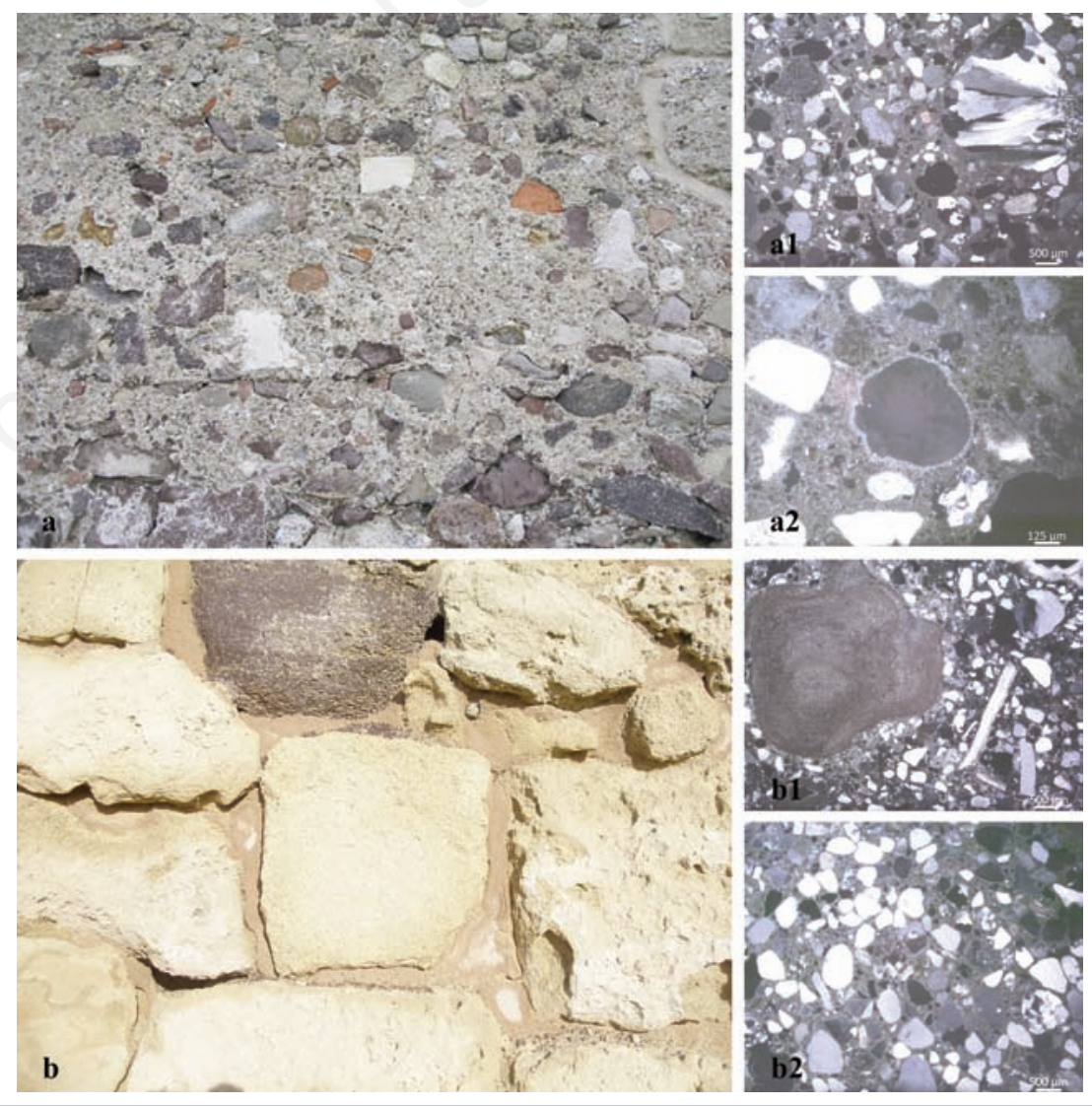

Figure 6. Plaster of the north prospectus (a) and mortar of the south façade (b). a1, a2) Thin section photomicrographs (crossed polarizer) of plaster with grained quartzfeldspar, volcanic and quartzite aggregates. The binder is micritic with cryptocrystalline reaction rims around mineral grains. b1-b2) Thin section photomicrographs (crossed polarizer) of mortar with grained quartz-feldspar and very poor volcanic and quartzite aggregates. The binder is micritic with lime lumps. 
the aggregate are also present brick chips.

The study of thin sections of plaster mortar showed the presence of grained quartzfeldspar and volcanic and quartzite aggregates. The binder is micritic with cryptocrystalline reaction rims around mineral grains (Elsen $e t$ al., 2004).

\section{Conclusions}

In conclusion, the reconstruction of the history of the construction of the bridge, with the support of the surveys and petrographic studies, has allowed us to begin a process that will shed light on its history and its constructive aspects.

The minero-petrographic investigation conducted on blocks and mortar put in evidence that the degradation affects only the segments of the sandstone arches, which show an incipient phenomenon weathering, while the volcanics are not altered, except the superficial changing of the patinas. The mortar of the wall continues to represent the weak point of the wall, and some parts are highly degraded.

Beyond the state of disrepair, serious damages can be attributed to human action. In fact, the structure is in poor conditions, mainly related to inadequate restoration, which have not complied with its material and documentary meaning.

This study, as already mentioned, is just the beginning of an ongoing project investigating the bridge, both from a historical-stratigraphic point of view, and from a materical point of view. Only with this in mind it will be possible from now on, to act in a respectful way, appreciating its architectural, techniques and structural features.

\section{References}

Bartoloni P, 1989. [Sulcis]. [Book in Italian]. Istituto Poligrafico e Zecca dello Stato ed., Roma, Italy.

Bernardini P, 1990. [I secoli della storia: la città romana]. In: P. Bernardini, D. Cocco, L.A. Marras (eds.) [Sulci: i secoli ritrovati]. [Book in Italian]. Sant'Antioco Municipality ed., Sant'Antioco, Italy, pp 3437.

Cagliari State Archive, 1839. [Tipi e profili, n. 31]. [Book in Italian]. Archivio di Stato di Cagliari ed., Cagliari, Italy.

Elsen J, Brutsaert A, Deckers M, Brulet R, 2004. Microscopical study of ancient mortars. Mater Charact 53:289-95.

Fois F, 1964. [I ponti romani della Sardegna]. [Book in Italian]. Gallizzi ed., Sassari, Italy.

Ghiotto AR, 2004. [L'architettura romana nelle città della Sardegna]. [Book in Italian]. Quasar ed., Rome, Italy.

Herrmann JJ, Herz N, Newman R, 2002. ASMOSIA 5. Interdisciplinary studies on ancient stone. Proceedings of the Fifth International Conference of the Association for the Study of Marble and Other Stones in Antiquity, Museum of Fine Arts, Boston, 1998. Archetype Publ. Ltd., London, UK.

Manconi D, 1976. Sulcis. In: R. Stillwell (ed.)
The Princeton enciclopedia of classical sites. Princeton University Press, Princeton, NJ, USA.

Mattazzi P, 1996. [L'istmo di Sulcis e il ponte romano: per una ricostruzione storica e topografica]. In: L. Quilici, S. Quilici Gigli (eds.) [Strade romane: ponti e viadotti]. [Book in Italian]. L'Erma di Bretschneider Publ., Rome, Italy, pp 251-258.

Meloni P, 1975. [La Sardegna romana]. [Book in Italian]. Chiarella ed., Sassari, Italy.

Meloni P, 1988. [La Sardegna romana. I centri abitati e l'organizzazione municipale]. [Book in Italian]. Walter De Gruyter Publ., Berlin-New York.

Prokos P, 2008. Equilbrium conditions of marine originated salt mixture: an ECOS application at archaeological site of Delos, Greece. In: Int.l Conf. on Salt Weathering on Buildings and Stone Sculptures. Technical University of Denmark ed., Copenaghen, Denmark, pp 139-149.

Spano G, 1857. [Raccolta dei monumenti antichi in ogni genere di tutta l'Isola di Sardegna]. [Book in Italian]. Available from: http://digi.ub.uni-heidelberg.de/ diglit/bullarchsardegna1857?sid=c472237 c36cae666b46adbf5d752d22d

Tronchetti C, 1984. [Sant'Antioco]. In: E. Anati (ed.) [I Sardi. La Sardegna dal Paleolitico all'età romana]. [Book in Italian]. Jaca Book, Milano, Italy, pp 144-146.

Tronchetti C, 1995. [Per la topografia di Sulci Romana]. In: P.G. Spanu (ed.) [Materiali per una topografia urbana. Status quaestionis e nuove acquisizioni]. [Book in Italian]. P.G. Spanu ed., Oristano, Italy, pp 103-115. 